\title{
Studi ketidakaktifan kader posyandu di Wilayah Kerja Puskesmas Paramasan, Banjar, Kalimantan Selatan
}

\author{
The study of integrated health post cadres inactivity in the Region of Paramasan Primary Health \\ Cares at Banjar Regency, South Kalimantan
}

Muhammad Ali Akbar¹, BJ. Istiti Kandarina², I Made Alit Gunawan ${ }^{3}$

\begin{abstract}
Background: Integrated health post is a community empowered health service that also supported by health workers. Cadres are the drive motor of integrated health post. Inactivity of cadres influence the continuity of integrated health post and affect nutritional status early detection of infants and children underfive. Paramasan Primary Health Care is a region in Banjar Regency that has the highest inactivity cadres level (54.5\%).

Objectives: To examine the knowledge of cadres, comprehensiveness of facilities and infrastructure at integrated health post, head of village and health workers support, incentives and awards, and community participation as the background of integrated health post cadres inactivity in Banjar Regency, South Kalimantan.

Methods: This was a descriptive research with qualitative methods using a case study design. The research was implemented in the Region of Paramasan Primary Health Cares at Banjar Regency, South Kalimantan in April until May 2014. Informants were selected by purposive sampling until get saturated data. The data collection was done by using 3 methods: in-depth interview of 23 informants, focus group discussion (FGD) of 30 informants, and field observation. Data analysis used in this study was constant comparative method.

Results: Cadres had very low knowledge never joined any training, and also illeterate. The facilities and infrastructure in integrated health post were very limited. Head of village support on cadres and integrated health post were also low. Unscheduled and unstable of incentive numbers and awards received by cadres was also a problem. The level of community participation was really depended on the activeness of cadres in reminding the schedule of integrated health postactivities.
\end{abstract}

Conclusions: The knowledge of cadres contibuted to the cadres inactivity, such as a poor participation and lack of confidence in attending the activities of the integrated health post.

KEYWORDS: cadres, inactivity, integrated health post

\begin{abstract}
ABSTRAK
Latar belakang: Posyandu merupakan wadah pelayanan kesehatan dari, oleh, dan untuk masyarakat dengan dukungan petugas kesehatan. Kader merupakan motor penggerak posyandu. Tidak aktifnya kader menyebabkan ketidaklancaran pelaksanaan posyandu serta tidak terdeteksinya status gizi bayi dan balita sejak dini. Puskesmas Paramasan merupakan salah satu wilayah di Kabupaten Banjar dengan tingkat ketidakaktifan kader tertinggi yaitu sebesar $54,5 \%$.

Tujuan: Mengkaji secara mendalam pengetahuan kader, kelengkapan sarana dan prasarana posyandu, dukungan kepala desa dan petugas kesehatan, insentif dan penghargaan kader, serta partisipasi masyarakat ke posyandu sebagai latar belakang ketidakaktifan kader posyandu.

Metode: Penelitian ini merupakan penelitian deskriptif dengan metode kualitatif menggunakan rancangan studi kasus. Pelaksanaan penelitian di wilayah kerja Puskesmas Paramasan Kabupaten Banjar Provinsi Kalimantan Selatan pada bulan April hingga Mei 2014. Informan dipilih secara purposive sampling,
\end{abstract}

\footnotetext{
Seksi Gizi, Dinas Kesehatan Kabupaten Banjar, Kalimantan Selatan, e-mail: alietrea94@gmail.com

2 Program Studi IImu Kesehatan Masyarakat Fakultas Kedokteran Universitas Gadjah Mada JI. Farmako Sekip Utara Yogyakarta

${ }_{3}$ Jurusan Gizi, Politeknik Kesehatan Yogyakarta, Jl. Tata Bumi No 3, Banyuraden, Gamping
} 
berlanjut hingga saturasi data. Pengumpulan data dilakukan dengan wawancara mendalam terhadap 23 orang informan, diskusi kelompok terfokus (DKT) terhadap 30 orang informan, dan observasi lapangan. Analisis data menggunakan metode constant comparative method.

Hasil: Kader memiliki pengetahuan kurang, tidak pernah mengikuti pelatihan, dan tidak bisa baca tulis. Sarana dan prasarana di posyandu sangat kurang, demikian pula dengan dukungan kepala desa terhadap kader, dan posyandu yang tergolong masih minim. Insentif dan penghargaan yang diterima kader dikategorikan tidak rutin dengan jumlah tidak tetap. Tingkat partisipasi masyarakat ke posyandu masih tergantung pada keaktifan kader dalam mengingatkan tentang hari buka posyandu.

Kesimpulan: Pengetahuan kader memberikan kontribusi terhadap ketidakaktifan kader yaitu kurangnya keaktifan dalam menghadiri kegiatan di posyandu.

KATA KUNCI: kader, ketidakaktifan, posyandu

\section{PENDAHULUAN}

Posyandu merupakan salah satu wadah komunikasi, alih teknologi dalam pelayanan kesehatan masyarakat dari masyarakat, oleh masyarakat dan untuk masyarakat dengan dukungan serta pembinaan teknis dari petugas kesehatan (1).

Keaktifan posyandu dipengaruhi oleh beberapa faktor, antara lain jumlah kader yang kurang, kader tidak aktif, serta kurangnya penghargaan untuk kader (2). Kader merupakan motor penggerak posyandu, sehingga hidup-matinya posyandu sangat tergantung dari aktif tidaknya kader (3). Kegiatan posyandu sangat tergantung pada kader, mereka dibutuhkan dalam pelayanan kesehatan dasar, karena merupakan ujung tombak sekaligus kepanjangan tangan puskesmas (4).

Ketidakaktifan kader posyandu di Kabupaten Banjar pada tahun 2013 sebesar 16,5\%. Di Puskesmas Paramasan, sejak tahun 2011 hingga 2013 dikategorikan sebagai wilayah dengan tingkat ketidakaktifan kader tertinggi yaitu $62,5 \%$ pada tahun 2011 , kemudian $61,5 \%$ pada tahun 2012 , dan $54,5 \%$ pada tahun 2013 (5).

Berdasarkan permasalahan masih tingginya angka ketidakaktifan kader posyandu dan dampak yang dapat terjadi, dikaji faktor yang menjadi latar belakang ketidakaktifan kader posyandu di wilayah kerja Puskesmas Paramasan Kabupaten Banjar, Provinsi Kalimantan Selatan.

\section{BAHAN DAN METODE}

Penelitian ini merupakan penelitian deskriptif dengan rancangan studi kasus, menggunakan metode kualitatif. Penelitian dilakukan di wilayah kerja Puskesmas Paramasan Kabupaten Banjar pada bulan April hingga Mei 2014. Informan utama adalah kader posyandu tidak aktif yang diambil secara purposive sampling sebanyak 6 orang. Pemilihan kader didasarkan pada kejenuhan informasi atau data yang diperoleh (saturasi), sedangkan informan pendukung terdiri atas 5 orang kader posyandu aktif, 3 orang kader posyandu drop-out, 3 orang kepala desa, 1 orang kepala puskesmas, 4 orang bidan desa, 1 orang petugas gizi puskesmas, dan 30 orang masyarakat pengguna posyandu, sehingga jumlah informan seluruhnya sebanyak 53 orang.

Karakteristik informan untuk kader posyandu yang tidak aktif yaitu kader yang dalam 1 tahun terakhir hadir ke posyandu $<8$ kali serta bersedia bekerjasama dalam memberikan informasi. Karakteristik informan untuk kader posyandu drop-out yaitu masyarakat yang pernah terdaftar sebagai kader posyandu dan tidak aktif lagi sebagai kader dalam 2 tahun terakhir, sedangkan karakteristik informan untuk masyarakat pengguna posyandu yaitu ibu balita yang rutin hadir ke posyandu dalam 6 bulan terakhir serta mampu mengutarakan pendapat dalam forum diskusi. Pengambilan informan untuk kepala desa, kepala puskesmas, bidan desa, petugas gizi puskesmas dan kader posyandu aktif dilakukan secara quota sampling.

Data diperoleh dengan teknik triangulasi, yaitu wawancara mendalam kepada kader posyandu tidak aktif, kader posyandu aktif, kader posyandu drop-out, kepala desa, kepala puskesmas, bidan desa dan petugas gizi puskesmas, diskusi kelompok terfokus (DKT) kepada masyarakat pengguna posyandu dan observasi lapangan ke posyandu 
yang ada. Penelitian ini telah mendapat surat kelayakan etik (ethical clearance) dari Komisi Etik Fakultas Kedokteran Universitas Gadjah Mada dengan nomor: Ref : KE/FK/3/3/EC tahun 2014.

\section{HASIL}

\section{Pengetahuan kader tentang posyandu}

Kader posyandu tidak mengetahui dengan baik tentang pengertian posyandu, kegiatan utama posyandu, maupun tugas mereka sebagai kader posyandu.Tentang pengertian posyandu, hampir semua kader menyatakan bahwa posyandu hanya sebagai tempat untuk mengetahui kesehatan, terutama kesehatan anak dengan kegiatan utamanya menimbang dan mencatat. Adapun tugas sebagai kader yang mereka ketahui hanya sebatas membantu mencacat, menimbang, maupun memberi bubur untuk balita, bahkan ada yang menyatakan tidak mengetahui tentang pengertian posyandu, seperti kutipan:

"Ya... menurut ulun apa yo, untuk mengetahui kita sehat atau kada" (WM- I.29)

(ya, menurut saya apa ya, untuk mengetahui kita sehat atau tidak)

"Me ituh, me anui kesehatan kekanakan" (WM-I.43)

(untuk itu, untuk mengetahui kesehatan anakanak)

"Pokoknya semunyaan gawiannya tu nah bisa digawi, mencatat kah, meolah buburnya kah, he-eh... semisalnya menimbang ya kita jua kaya itu nah" (WM-I.10)

(pokoknya semua pekerjaan itu bisa dikerjakan, mencatat, membuat bubur, semisalnya untuk menimbang juga seperti itu)

Hampir semua kader menyatakan belum pernah mengikuti kegiatan pelatihan kader posyandu, sehingga mereka merasa pengetahuan yang mereka miliki masih kurang. Hal ini lah yang kemudian membuat mereka tidak aktif sebagai kader posyandu, sesuai ungkapan berikut:

"Kada biasa" (WM-I.32), (WM-I.44) (tidak pernah)
"He-eh... karena kurang tahu tentang posyandu" (WM-I.32)

(iya, karena kurang mengetahui tentang posyandu)

"Inggih... jadi asa kulir kaya itu nah inya kada tapi bisa ulun, embah anu begana meliatakan urang tuh, melihatakan bubuhan ruslan, buhan anu ni ti" (WM-I.18)

(iya, jadi merasa malas seperti itu karena saya tidak terlalu mengetahui, terkadang hanya berdiam diri membiarkan mereka, membiarkan Pak Ruslan dan petugas lainnya)

\section{Kelengkapan sarana dan prasarana}

Posyandu yang digunakan warga sebagian besar belum memiliki bangunan khusus untuk posyandu. Tempat yang biasa digunakan adalah bangunan pos ronda, rumah warga dan sekolah, serta rumah bidan desa, berikut kutipannya: "Kadeda... digardu ti pang" (DKT-I39)
(tidak ada, ya di pos ronda ini
pelaksanaannya)

"Rumahnya kada ada, rumahnya nang pinjaman haja, bilanya buhan ustadz kada ada turun, buhan guru disiya kadada, kamana lagi inya bamalam, paling di anu ti pang disakulahan" (DKT-I.46)

(bangunannya tidak ada, hanya pinjam rumah pak ustadz dan kalau beliau pergi atau menginap ke mana, biasanya diselenggarakan di sekolahan)

"Rumah ibu bidan" (WM- I.29)

Kader posyandu tidak aktif menyatakan bahwa sarana dan prasarana yang sangat minim tersebut bukan sebagai penyebab mereka tidak aktif ke posyandu, melainkan disebabkan tidak tepatnya petugas datang ke posyandu dari jadwal yang sudah ada, sehingga terjadi perselisihan antara kedatangan petugas kesehatan dengan kader yang pergi bekerja. Berikut kutipan wawancaranya:

"Embah anu kada tahu, kada ingat kalo itu memadahakan kaya itu nah, tatulak kahutan jua" (WM-I.32)

(terkadang tidak tahu, mungkin tidak ingat 
memberitahukan ke kami jadwalnya barunya, sehingga kami pergi bekerja)

"Marga tasulisih aja... (tertawa)" (WM-I.44) (hanya karena selisih aja)

\section{Dukungan kepala desa dan petugas kesehatan}

Hasil wawancara dengan kader tidak aktif, hampir seluruhnya menyatakan tidak adanya dukungan yang diberikan oleh kepala desa, sedangkan dukungan dari petugas kesehatan rutin mereka terima setiap bulannya. Meskipun dukungan maupun peran kepala desa turut menentukan maju tidaknya posyandu di desa, hal tersebut bukan sebagai penyebab mereka tidak aktif hadir ke posyandu, melainkan karena faktor lain seperti sibuk serta karena kondisi jalan yang tidak memungkinkan, seperti ungkapan berikut:

"Itu pembakal ti nang ngaran sidin bisnis... (terdengar suara motor), jadi kada tahu di kampung lagi, biar napa-napa masalahnya kada tahu" (WM-I.43)

(kepala desanya sibuk bisnis, sehingga tidak mengetahui lagi keadaan desa, masalah apapun yang terjadi tidak mengetahui lagi).

"Kada pang, ulun kada masalah pembakal tu... (tertawa), biar sidin kada datang mun saurang handak datang, kawa haja han lakonnya, masalah aur ti pak ai, inggih kahutan, ni gin handak kahutan han kami" (WM-I.18)

(tidak juga, kepala desa bukan menjadi masalah bagi saya, meskipun dia tidak datang, kalau kita sendiri mau datang, bisa saja nanti, permasalahannya karena sibuk bekerja saja)

"Halangannya biasanya kan kalo hujan jalannya kan ngalih, licak kaya itu" (WM-I.29)

(halangannya biasanya karena hujan, jalannya menjadi susah, menjadi becek).

\section{Insentif dan penghargaan}

Insentif dan penghargaan yang diberikan untuk kader posyandu diharapkan dapat dijadikan sebagai motivasi bagi kader agar menjadi lebih aktif hadir ke posyandu. Akan tetapi, berdasarkan hasil wawancara dengan kader posyandu tidak aktif mengatakan, mereka tidak aktif bukan disebabkan sedikit maupun tidak adanya insentif dan sertifikat penghargaan yang mereka terima, melainkan karena hal lain seperti kondisi jalan yang rusak maupun karena jarak rumah yang jauh. Hal ini karena pada dasarnya mereka ikhlas meskipun tidak mendapatkan imbalan, sesuai kutipan berikut:

"Ya... marga jalan tadi aja" (WM-I.29)

(ya hanya karena faktor jalannya saja)

"Kalo wayah ini kan pindah ke sini ke ujung jadi jauh, jauh jadi kadang-kadang hujan apa, kada kawa aktif lagi kesitu" (WM-I.10) (kalau sekarang sudah pinah ke ujung, jadinya jauh, sehingga kalau turun hujan, tidak bisa aktif ke posyandu disana)

"Kada marga duit apa, terserah buhan bu lisa ai... dibari ti lakunnya mun rela... disyukuri" (WM-I.43)

(bukan karena uang atau apa, terserah ibu bidan lisa saja, kalau mereka memberi dengan rela, saya syukuri)

\section{Partisipasi masyarakat hadir ke posyandu}

Tingkat kehadiran masyarakat ke posyandu sangat tergantung dari keaktifan kadernya. Apabila mereka tidak aktif, maka masyarakat juga menjadi tidak aktif ke posyandu, sesuai kutipan berikut:

\footnotetext{
"Inggih... supaya bila kita aktif han otomatis urang tu aktif jua meliat kita ni baik han, memembimbing yang urang kampung nih, jadi urang kampung tu ada tarus, mun kita nya kada aktif, otomatis inya kada mau datang, kaya itu" (WM-I.17)

(iya, apabila kita aktif maka otomatis orang juga aktif karena melihat kita baik, membimbing masyarakat, sehingga masyarakat selalu ada, kalau kita tidak aktif, otomatis masyarakat tidak mau datang, seperti itu)
}

Kader posyandu tidak aktif, menyatakan bahwa tidak aktifnya mereka ke posyandu bukan disebabkan partisipasi masyarakat rendah maupun tinggi, melainkan karena selisih/tidak bertemu dengan kedatangan petugas serta jarak rumah yang jauh, sesuai kutipan berikut: 
"Inggih, tasulisih... (tertawa)" (WM-I.44) (iya, karena selisih)

"Kada, kadeda masalah yang lain kadeda... faktorjauh haja... faktor jauh lawan kandaraan kada ada... (tertawa)" (WM-I.10)

(tidak, tidak ada permasalahan yang lainnya, faktor jauh saja, faktor jauh kemudian tidak punya kendaraan"

\section{BAHASAN}

\section{Pengetahuan kader tentang posyandu kontribusinya dengan ketidakaktifan kader}

Hasil penelitian diketahui bahwa pengetahuan kader posyandu baik itu tentang pengertian posyandu, kegiatan utama posyandu, maupun tugas mereka sebagai kader posyandu masih kurang. Hal ini karena sebagian besar kader memang belum pernah mengikuti kegiatan pelatihan kader.

Kenyataan demikian terjadi di lapangan. Hal ini membuat kader semakin malas dan tidak percaya diri serta tidak bisa berbuat banyak dalam kegiatan posyandu. Tidak adanya kesempatan untuk mengikuti kegiatan pelatihan kader membuat pengetahuan kader semakin berkurang, yang pada akhirnya membuat kader semakin tidak aktif ke posyandu. Dengan demikian dapat disimpulkan bahwa pengetahuan kader yang kurang memberikan kontribusi terhadap ketidakaktifan kader dengan membuat kader menjadi malas maupun tidak percaya diri untuk hadir dan terlibat dalam kegiatan penimbangan bulanan di posyandu.

Pengetahuan merupakan faktor/landasan awal yang dapat mempermudah terjadinya perilaku pada diri seseorang atau masyarakat berperilaku kesehatan, dalam hal ini ketidakaktifan kader untuk hadir ke posyandu (6). Hal ini sesuai penelitian yang menyatakan bahwa seorang kader akan aktif dalam kegiatan posyandu setelah ia tahu tujuan dan manfaat posyandu bagi kesehatan, khususnya ibu dan anak, serta tahu akibat bila tidak aktif ke posyandu (7). Semakin baik pengetahuan kader, maka semakin meningkat ketrampilan kader dalam menilai kurva pertumbuhan balita yang membuat mereka semakin aktif ke posyandu (8). Hal senada dinyatakan pada penelitian sebelumnya yang menemukan masih rendahnya tingkat pengetahuan tenaga nonkesehatan seperti kader terutama tentang risiko dan komplikasi kehamilan serta persalinan, sehingga perlu untuk ditingkatkan (9).

\section{Kelengkapan sarana dan prasarana posyandu kontribusinya dengan ketidakaktifan kader}

Hasil penelitian menunjukkan bahwa sarana dan prasarana yang ada di posyandu sebagian besar belum merata, masih terbatas, dan sangat sederhana baik dari segi jumlah maupun kualitasnya. Tidak lengkapnya sarana prasarana posyandu selain karena ketergantungan dari pihak dinas kesehatan juga karena kurangnya koordinasi lintas sektor terutama dari kepala desa dan PKK, baik PKK kecamatan maupun PKK desa.

Tidak lengkapnya sarana dan prasarana di posyandu bukan sebagai penyebab kader menjadi tidak aktif ke posyandu. Selama ini, kader tetap melakukan kegiatan posyandu serta penimbangan meskipun dengan segala keterbatasan sarana dan prasarana yang ada. Ketidaktepatan waktu petugas datang ke posyandu merupakan penyebab ketidakaktifan kader karena adanya antara kedatangan petugas kesehatan dengan kader yang pergi bekerja.

Meskipun tidak aktifnya kader bukan disebabkan lengkap atau tidaknya sarana dan prasarana, namun sarana dan prasarana tetap harus dilengkapi dan disediakan karena tanpa sarana yang memadai, pelayanan yang diberikan ke masyarakat tidak akan optimal. Untuk mengaktifkan kembali seluruh kader, maka sarana prasarana harus segera dilengkapi karena ada salah seorang kader yang menyatakan bahwa dia menjadi malas ke posyandu karena kurangnya peralatan yang ada.

Kelengkapan sarana dan prasarana di posyandu merupakan faktor penting yang tidak bisa diabaikan guna kelancaran kegiatan penimbangan di posyandu. Dinas kesehatan berperan membantu pemenuhan pelayanan sarana dan prasarana (pengadaan alat timbangan, distribusi kartu menuju sehat (KMS), obat-obatan, dan vitamin) serta dukungan bimbingan teknis kesehatan (10).

Sesuai penelitian sebelumnya, tidak bergairahnya pemanfaatan posyandu oleh masyarakat karena 
kurangnya fasilitas termasuk tempat dan sarana yang tidak memadai. Dinyatakan pula bahwa salah satu motivasi ibu membawa anaknya ke posyandu adalah karena adanya alat permainan anak di posyandu, sehingga anak dapat bermain sambil menunggu giliran untuk ditimbang (11). Hal senada diungkapkan penelitian yang menyatakan bahwa permasalahan yang sering dikeluhkan oleh kader posyandu antara lain timbangan yang sudah rusak, tidak tersedianya buku register, kurangnya sarana untuk penyuluhan serta tempat untuk kegiatan posyandu yang kurang memadai (12).

\section{Dukungan kepala desa dan petugas kesehatan kontribusinya dengan ketidakaktifan kader}

Kurangnya dukungan kepala desa ternyata bukan merupakan hal yang membuat kader menjadi tidak aktif ke posyandu, ada sebab lain seperti kesibukan bekerja serta fasilitas jalan yang tidak mendukung untuk pergi ke posyandu, terutama pada saat musim penghujan. Di balik itu, penulis menangkap bahwa sebenarnya para kader tetap memerlukan dukungan dari kepala desa, karena pengambil kebijakan atau keputusan tertinggi berada di kepala desa. Hal ini disebabkan segala keperluan posyandu membutuhkan persetujuan kepala desa, baik untuk penyediaan bangunan, lokasi, peralatan yang dibutuhkan, maupun dana operasional posyandu yang bisa dianggarkan melalui kas desa atau sesuai kebijakan kepala desa. Dengan demikian, diharapkan posyandu dapat berjalan dengan baik setiap bulannya.

Untuk mengaktifkan seluruh kader, maka dukungan kepala desa tetap harus ada dan rutin diberikan baik itu kepada kader maupun posyandu. Hal ini berdasarkan informasi dari salah seorang kader yang menyatakan bahwa tidak adanya dukungan dari kepala desa, membuat kader tersebut menjadi tidak aktif ke posyandu. Perlunya motivasi positif dari seorang pimpinan masyarakat, dalam hal ini kepala desa untuk memberikan hadiah atau reward kepada anggota masyarakat (kader posyandu) dapat memacu perilaku/partisipasi kader menjadi lebih baik. Hadiah atau reward dapat berupa uang, barang atau nonmaterial, seperti piagam atau sekadar pujian berupa kata-kata lisan (13).
Berkenaan dengan petugas kesehatan, dinyatakan bahwa kehadiran tenaga kesehatan diwajibkan di posyandu satu kali dalam sebulan guna membimbing kader menyelenggarakan pelayanan kesehatan dan KB, penyuluhan dan konseling kesehatan dan gizi, menganalisis hasil kegiatan posyandu, deteksi dini tanda bahaya umum terhadap ibu hamil, bayi dan balita, serta melakukan rujukan ke puskesmas apabila dibutuhkan (10).

Sudah sangat jelas bahwa dukungan kepala desa dan petugas kesehatan terhadap posyandu mengindikasikan bahwa peran mereka sangat penting dan tidak bisa diabaikan guna kelancaran kegiatan posyandu. Hal ini sesuai penelitian yang menyatakan bahwa desa yang kadesnya selalu memberikan motivasi pada kegiatan posyandu akan lebih baik kinerja dan kelestarian posyandunya dibandingkan dengan desa yang kadesnya tidak memberi motivasi sama sekali (14) dan dinyatakan juga bahwa kehadiran petugas kesehatan menjadi salah satu daya tarik bagi ibu-ibu balita untuk berkunjung ke posyandu, karena dapat secara langsung mengetahui perkembangan balitanya dari petugas kesehatan (11). Begitu juga penelitian lain, kehadiran petugas kesehatan di posyandu selain untuk memberikan pelayanan kesehatan, sekaligus bersifat supervisi lapangan yang dapat menggantikan kegiatan pelatihan, karena saat melakukan supervisi bisa secara langsung memperbaiki kesalahpahaman dan praktik-praktik di bawah standar yang dilakukan kader (15).

\section{Insentif dan penghargaan kader kontribusinya dengan ketidakaktifan kader}

Tidak adanya insentif dan penghargaan yang diterima kader bukan sebagai hal yang menyebabkan kader tidak aktif ke posyandu. Di balik itu, insentif dan penghargaan tetap mereka butuhkan guna pemacu semangat mereka untuk lebih aktif karena tidak ada seorang pun di dunia ini yang tidak membutuhkan uang sekaligus penghargaan. Hal ini terlihat dari harapan kader yang pada dasarnya mereka mengharapkan adanya hasil atau gaji serta minta dihargai atas jerih payahnya selama ini. Begitu juga untuk membuat aktif kembali seluruh kader, maka insentif dan penghargaan sebaiknya 
juga diberikan karena diketahui dari salah seorang kader yang menyatakan bahwa dia menjadi tidak bersemangat ke posyandu karena tidak adanya insentif.

Pemberian materi atau nonmateri kepada orang secara langsung untuk memenuhi kebutuhan merupakan cara yang langsung dapat meningkatkan motivasi kerja. Pemberian materi dapat berupa pemberian uang atau bonus, serta pemberian hadiah pada waktu tertentu, sedangkan pemberian nonmateri antara lain dengan memberikan pujian, penghargaan dan tanda kehormatan lainnya, baik dalam bentuk surat atau piagam (13). Meskipun pekerjaan kader sebagai relawan, namun kader masih mengharapkan adanya insentif yang memadai dan penghargaan yang lebih layak. Penghargaan atau reward sangat penting untuk menunjang peningkatan kinerja kader (4) dan penelitian lain menemukan bahwa kader mempunyai harapan mendapatkan insentif dari pemerintah tiap bulannya, mendapatkan baju seragam tiap tahunnya serta mengharapkan adanya tunjangan hari raya (THR) (12).

Adanya penghargaan yang diberikan kepada kader selaku penanggungjawab di posyandu ternyata memiliki kontribusi yang bermakna untuk faktor motivasi internal guna aktif sebagai kader. Penghargaan yang umumnya diinginkan adalah rasa hormat dan status dalam berbagai bentuk, antara lain pujian, pengakuan atas prestasi, dan pemberian simbol status (kekuasaan) termasuk juga memperoleh penghargaan dalam keterlibatannya di kegiatan posyandu (16). Kebutuhan akan penghargaan merupakan kebutuhan prestise dan bukan monopoli bagi pejabat atau pimpinan organisasi saja, serendah apa pun kedudukan maka kebutuhan akan penghargaan muncul atau ingin dipenuhi. Pemberian penghargaan (reward) bukan didasarkan pada lama kerja atau model arisan melainkan didasarkan pada prestasi kerjanya (13).

\section{Partisipasi masyarakat hadir ke posyandu kontribusinya dengan ketidakaktifan kader}

Partisipasi masyarakat khususnya ibu balita hadir ke posyandu menjadi sangat baik (sesuai jadwal) bila beberapa hari sebelumnya ada pemberitahuan terlebih dahulu oleh kader, posyandu, dan petugas kesehatan. Tidak aktifnya kader akan berdampak pada tidak aktifnya masyarakat hadir ke posyandu. Hal ini disebabkan ketergantungan posyandu pada kader, demikian pula ketergantungan masyarakat pada informasi dari seorang kader. Kader merupakan motor penggerak posyandu, hidup matinya posyandu sangat tergantung dari aktif tidaknya kader (3).

Hasil penelitian menemukan bahwa tinggi atau rendahnya partisipasi masyarakat ke posyandu bukan sebagai penyebab ketidakaktifan kader, melainkan karena selisih/tidak bertemu dengan kedatangan petugas serta jarak rumah yang jauh dari posyandu. Meskipun ketidakaktifan kader bukan disebabkan oleh tingkat partisipasi masyarakat, penulis menarik kesimpulan bahwa partisipasi masyarakat untuk hadir ke posyandu tetap harus tinggi, karena tujuan didirikannya posyandu memang untuk masyarakat. Apabila masyarakat tidak hadir, maka posyandu tidak akan berjalan karena masyarakatlah sasaran utama posyandu.

Tanpa dukungan dan partisipasi masyarakat, maka sulit suatu program pembangunan tidak bisa berhasil karena masyarakat termasuk pelakunya (subjek) dan sasaran (objek) dari pembangunan. Partisipasi masyarakat ke posyandu erat kaitannya dengan ketepatan jadwal buka posyandu, seperti yang diungkapkan penelitian lain, bahwa ibu balita enggan datang ke posyandu karena jadwal buka posyandu yang terlalu siang (17) dan jadwal kegiatan posyandu sepatutnya menyesuaikan diri dengan situasi ibu-ibu dalam masyarakat (15).

\section{KESIMPULAN DAN SARAN}

Pengetahuan kader yang kurang tentang posyandu memberikan kontribusi terhadap ketidakaktifan kader dalam bentuk rasa malas dan kurang percaya diri dalam menghadiri kegiatan di posyandu. Kelengkapan sarana dan prasarana, dukungan kepala desa dan petugas kesehatan, insentif dan penghargaan kader serta partisipasi masyarakat ke posyandu tidak memberikan kontribusi terhadap ketidakaktifan kader.

Berdasarkan kesimpulan tersebut, maka diharapkan kepada pihak puskesmas untuk dapat: memberikan pelatihan kepada kader yang tidak bisa membaca dan menulis dengan cara pemberian 
gambar-gambar tentang kegiatan sistem 5 langkah di posyandu serta bekerjasama dengan kepala desa dan guru setempat memberikan reward kepada kader berupa pelajaran membaca dan menulis. Selain itu, rapat musyawarah pimpinan kecamatan (MUSPIKA) hendaknya mengajak kepala desa dan PKK Kecamatan membahas permasalahan posyandu serta menghimbau agar setiap ada kegiatan pelatihan kader hendaknya berkoordinasi terlebih dahulu dengan pihak puskesmas, kerjasama dengan kepala desa untuk mengintensifkan kembali kegiatan penyuluhan kesehatan terutama tentang pentingnya posyandu bagi masyarakat juga hendaknya dilaksanakan. Kerjasama dengan dinas kesehatan untuk segera melengkapi kekurangan sarana prasarana di posyandu serta membangun rumah bidan desa. Kepala desa hendaknya juga menyampaikan semua kebijakan tentang posyandu kepada kader, mengupayakan perbaikan jalan serta membangun posyandu di lokasi yang dekat dengan pemukiman guna memudahkan masyarakat untuk hadir ke posyandu.

\section{RUJUKAN}

1. Alamsyah D. Pemberdayaan gizi teori dan aplikasi. Yogyakarta: Nuha Medika; 2013.

2. Kementerian Kesehatan Republik Indonesia. Panduan tenaga pelaksana gizi puskesmas dalam pembinaan kader posyandu. Jakarta: Kementerian Kesehatan Republik Indonesia; 2012b.

3. Departemen Kesehatan RI. Buku kader: telaah kemandirian posyandu. Jakarta: Departemen Kesehatan RI; 2000.

4. Simanjuntak M. Karakteristik sosial demografi dan Faktor pendorong peningkatan kinerja kader posyandu. J Wira Ekon Mikroskil. 2012; 2(1):49-58.

5. Dinas Kesehatan Banjar. Laporan tahunan program perbaikan gizi masyarakat tahun 2013. Martapura: Dinas Kesehatan Banjar; 2013.

6. Notoatmodjo S. Promosi kesehatan: teori dan aplikasi. Jakarta: Rineka Cipta; 2010.

7. Nugroho H, Nurdiana D. Hubungan antara pengetahuan dan motivasi kader posyandu dengan keaktifan kader posyandu di Desa Dukuh Tengah Kecamatan Ketanggungan Kabupaten Brebes. J Keperawatan. 2008;2(1):1-8.

8. Hamariyana, Syamsianah A, Winaryati E. Hubungan pengetahuan dan lama kerja kader dengan ketrampilan kader dalam menilai kurva pertumbuhan balita di Posyandu Kelurahan Tegal Sari Kecamatan Candisari Kota Semarang. J Gizi Univ Muhammadiyah Semarang. 2013; 2(1):40-8.

9. Rukmini, Suharmiati, Ristrini. Gambaran tingkat pengetahuan, sikap, dan perilaku nakes terhadap faktor risiko dan komplikasi kehamilan dan persalinan sebagai upaya peningkatan rujukan. Bul Penelit Sist Kesehat. 2009; 12(1): 34-41.

10. Kementerian Kesehatan Republik Indonesia. Pedoman umum pengelolaan posyandu. Jakarta: Kementerian Kesehatan Republik Indonesia; 2012.

11. Handajani A, Muzakkiroh U, Rukmini. Upaya pengembangan posyandu madya dan purnama menjadi posyandu mandiri. Bul Penelit Sist Kesehat. 2009; 12(1): 21-33.

12. Nikmawati E, Kusharto $C$, Khomsan $A$, Sukandar D, Atmawikarta A. No Title. J GIZI PANGAN. 2009; 4(3):140-50.

13. Notoatmodjo S. IImu perilaku kesehatan. Jakarta: Rineka Cipta; 2010b.

14. Widagdo L. Kepala desa dan kepemimpinan perdesaan: persepsi kader posyandu di Kecamatan Mlonggo Kabupaten Jepara Jawa Tengah 2000. Makara Kesehat. 2006; 10(2): 54-9.

15. Saripawan Y, Hasanbasri M. Implementasi posyandu supervisi oleh Puskesmas di Pontianak. J Manaj Pelayanan Kesehat. 2007; 10(2): 90-7.

16. Djuhaeni $\mathrm{H}$. Motivasi kader meningkatkan keberhasilan posyandu. MKB. 2010; 42(4): 140-8.

17. Rahmadiliyani M, Meililiyanie. Analisis faktorfaktor yang menyebabkan keengganan ibu balita berkunjung ke posyandu di Desa Jingah Habang Hilir Kecamatan Karang Intan Kabupaten Banjar. Media Sains. 2012; 4(2): 160-5. 